\title{
Who am I Online? Understanding the Meaning of Online Contexts for Identity Development
}

\author{
Maria Wängqvist ${ }^{1}\left[\right.$ Ann $^{-}$Frisén $^{1}$
}

Received: 9 December 2015/ Accepted: 26 February 2016/Published online: 14 March 2016

(C) Springer International Publishing 2016

\begin{abstract}
Research concerning the function of online contexts in adolescents' everyday lives adds important pieces to the understanding of their identity development. Specifically, online contexts are distinguished from other everyday contexts with regard to the conditions for identity explorations, self-presentations, and social interactions. Understanding the meaning of these aspects of online contexts for identity development is thus an important research area. This review of research of identity online shows that research has so far primarily focused on identity expressions and less on identity development. Conversely, developmental identity research rarely includes online contexts. Thus, there is a gap between research about identity development and research about identity online. This article, therefore, aims to review research on identity online from a developmental perspective and to suggest directions for future research. The reviewed literature was structured around aspects where online contexts have brought about substantially changed conditions for identity development: the opportunities for identity explorations, means for self-presentations, and requisites for social interactions. The conclusions are that research on identity development may further the understanding of adolescents' online activities and that research on identity development needs to include online contexts to see the whole story of identity development for adolescents today.
\end{abstract}

Keywords Online contexts - Identity development . Identity processes $\cdot$ Identity integration

Maria Wängqvist

maria.wangqvist@psy.gu.se

1 Department of Psychology, University of Gothenburg, Box 500, 40530 Gothenburg, Sweden

\section{Introduction}

Today, most young people's everyday lives take place online as well as offline (Turkle 1995; Valkenburg and Peter 2011) and online contexts may thus be described as important settings for identity development, in addition to offline contexts such as the home and school. However, little is known about what adolescents' involvement on online contexts really mean for their identity development, even though, both in research and societal discourses, online contexts are usually assumed to be very important in identity development. This article, therefore, reviews the interdisciplinary research about identity online from a developmental perspective. The purpose of the review is to make suggestions for how a developmental framework may further this knowledge and stimulate future research programs addressing issues concerning online contexts and adolescents' identity development.

The review is guided by a developmental framework. In short, within this framework, identity is defined as a subjective experience of who one is (Kroger and Marcia 2011), which offers a sense of coherence across time and place and across social roles (Erikson 1968). Identity development is the process through which identity elements (e.g., personal characteristics, wishes, goals, roles, identifications, and mirroring from others) are gradually integrated into the evolving identity configuration (Erikson 1980). The sense of identity develops through processes such as exploration and commitment (Kroger and Marcia 2011), and autobiographical reasoning (McAdams 2001); and in interaction with individuals' social contexts. Recent metaanalyses and reviews of identity status research (Kroger et al. 2010; Meeus 2011) also indicate that there is substantial stability in identity development, even in adolescence. Research has started to focus on some of the 
developmental processes behind this stability (Carlsson et al. 2015), indicating that exploration and commitment do not show the whole picture of identity development. Unfortunately, developmental identity research (see e.g., Schwartz et al. 2011) rarely studies or integrates online contexts and significant aspects of adolescents' identity development may thus be left out. Investigations of the meaning of online contexts for identity development might add valuable knowledge about the ways in which identity processes are contextualized.

\section{Current Study}

The purpose of the present study is to review what may be learned about adolescents' identity development from the existing literature on identity online and to make suggestions for how a developmental framework may guide hypotheses and investigations in future research programs concerned with the meaning of online contexts in adolescents' development. The review thus concern research that directly addresses the issue of identity in online contexts, even though we recognize that other lines of research may certainly inform these issues as well.

In our review of the literature we addressed the aim in two steps. First, we investigated the Identity definitions, Methodologies, Participants, Online contexts and Main findings and conclusions in the reviewed studies of identity online. This first step is important since the research is interdisciplinary, builds on different theoretical and methodological traditions, and investigates different online contexts. Based on the first step, we organized the findings from the reviewed literature into broader themes in order to describe and discuss their contribution to the understanding of the meaning of online contexts in identity development, and to identify what research questions remain to be answered. This analysis of the reviewed literature is closely tied to the aim of investigating the research from a developmental perspective to see what may be learned from that research and how the knowledge may be furthered by a developmental perspective.

\section{Methods}

\section{Article Search}

The database PsycINFO was used to search for articles and searches included combinations of the search terms: identity, online, internet, social media, and social networking sites (SNS). The search was specified to only include peerreviewed articles and the search terms should be found in either the title or as key words. The different combinations of the search terms resulted in between 68 (for identity and social networking sites) and 1613 (for identity and social media) results. See Table 1 for the number of articles found in the searches in total and when the searches where limited to, first, only include studies published since 2000 and, then, studies published since 2010. In short, the search revealed that the vast majority of studies were published after 2010, and that very few studies were published before 2000. The final searches were made in August 2015.

The reason to use primarily PsycINFO in our search for articles was the developmental framework of this study. PsycINFO offers access to international literature in psychology and related disciplines and the reason to use PsycINFO was that this would guarantee the most relevant articles from a psychological perspective. However, we also made searches in PubMed to make sure that our review did not miss out on important articles for the reviewed topic.

\section{Inclusion Criteria}

The purpose of this study was to review the literature on identity online from a developmental perspective and therefore we excluded articles where the definition of identity was too far from definitions of identity as an intraand inter-individual process, for example by defining and operationalizing identity as merely revealing one's true name or not. Articles were selected due to their relevance for research on adolescence, either by having adolescent participants or investigating identity issues salient in adolescent development.

There are also several other lines of research that are highly relevant when trying to understand the meaning of online contexts for identity development. For example, research on social relationships or cyberbullying may add to this understanding. Although we do refer to some of these research areas in our discussion of the reviewed literature, an inclusion criteria for this review was that the articles explicitly studied identity, and had identity either in the title or as a specified key word.

The articles included in this review were selected to reflect the different lines of research on identity online. Because of the constantly changing online environment priority was given to newer references, from 2010 and onwards. However, some older references were included because of their high relevance for the topic in this study, because they represent seminal work within this area of research, or in order to make sure that the lines of research within this area were properly represented.

\section{Review of Articles}

We used a coding system, displayed in Table 2, to review (1) the Identity definition in the study, (2) the Methodology 
Table 1 Results from the Search for Peer-Reviewed Articles on the Database PsycINFO

\begin{tabular}{|c|c|c|c|}
\hline Search terms & $\begin{array}{l}\text { Total number } \\
\text { of articles }\end{array}$ & $\begin{array}{l}\text { Articles published since } \\
2000 \text { (\% of total) }\end{array}$ & $\begin{array}{l}\text { Articles published since } \\
2010 \text { (\% of total) }\end{array}$ \\
\hline 'Identity' and 'Internet' & 1158 & $\begin{array}{l}1142 \\
(98.6 \%)\end{array}$ & $\begin{array}{c}744 \\
(64.2 \%)\end{array}$ \\
\hline 'Identity' and 'Online' & 962 & $\begin{array}{c}957 \\
(99.4 \%)\end{array}$ & $\begin{array}{c}721 \\
(74.9 \%)\end{array}$ \\
\hline 'Identity' and 'Social media' & 1613 & $\begin{array}{l}1543 \\
(95.7 \%)\end{array}$ & $\begin{array}{l}1112 \\
(68.9 \%)\end{array}$ \\
\hline 'Identity' and 'Social Networking Sites' & 68 & $\begin{array}{c}68 \\
(100 \%)\end{array}$ & $\begin{array}{c}55 \\
(80.9 \%)\end{array}$ \\
\hline
\end{tabular}

The table shows the total number of articles found when using the different search terms (included in the title or as key words) without limiting the time-span, as well as the number (and percentages) of these articles that were published since 2000 and 2010

Searches ended in August 2015

they used to study identity online, (3) who and how many the Participants were, (4) which Online context or contexts were investigated, and (5) what the Main findings and conclusions were. Based on this analysis of the articles we then reviewed how they added to the understanding of identity online by organizing them into broader themes.

\section{Results}

Based on our first review of the identity definitions, methodologies, participants, which online contexts they investigated, and the main findings and conclusions in the reviewed articles (presented in Table 2), we organized their findings into three broader themes. The following presentation of the review is structured in sections addressing these themes that represent aspects where online contexts have brought about substantially changed conditions for identity development; the opportunities for identity explorations, means for self-presentations, and requisites for social interactions.

\section{Opportunities for Identity Explorations: Aspects of Identity that are Constrained in Offline Contexts May be Expressed and Explored Online}

An important characteristic of online contexts in terms of identity development is that participation in online contexts is less dependent on geographical proximity and time compared to offline contexts, which may make more contexts available for identity exploration and experimentations (Shapiro and Margolin 2014). The independence of time and physical distance may be particularly salient for adolescents who experience challenges in expressing aspects of their identity in their traditional offline contexts, such as minority youth (boyd 2014; Shapiro and Margolin
2014), and individuals who for different reasons (such as shyness) experience difficulties in face-to-face interactions. The knowledge gained from studies on internet usage among particular groups of people may well apply to the understanding of adolescents' identity development in general as well. Below we describe the reviewed literature that adds to this understanding of identity explorations in online contexts.

The part of the reviewed research that concerned how individuals identifying with specific social identities used online contexts in their identity development, mainly dealt with sexuality and ethnicity. First, with regards to sexuality, the research showed that adolescents identifying with a sexual minority felt more at ease in expressing their sexuality and connecting with others in online contexts than they did offline (Hillier and Harrison 2007). It was also found to be important for identity development and wellbeing that they could transfer the identity aspects they explored and developed online to offline contexts (Crowson and Goulding 2013; DeHaan et al. 2012). In the reviewed research that concern ethnic minorities, it was argued that online contexts may strengthen individuals' ethnic identity by making contexts beyond the offline environment available (Markstrom 2011). The research showed that individuals in ethnic minorities tended to emphasize cultural aspects in their online self-presentations (Grasmuck et al. 2009). This research on affordances from online contexts for individuals with difficulties to express aspects of their identities in their offline contexts, implicate that the more or less concealed aspects of identity that everybody has, may develop and be expressed online, but it also highlight the importance of integrating views of oneself from online contexts into other contexts and salient relationships.

The reviewed research also revealed some contradictory findings. A study with adolescent girls who identified with 
Table 2 Summary of Articles on Identity Online

\begin{tabular}{|c|c|c|c|c|c|}
\hline Study & Identity definition/focus & Methodology & Participants & Online context & $\begin{array}{l}\text { Main findings and } \\
\text { conclusions }\end{array}$ \\
\hline $\begin{array}{l}\text { Bargh et al. } \\
\text { (2002) }\end{array}$ & Self-presentation & $\begin{array}{l}\text { Experimental conditions, } \\
\text { including self- } \\
\text { descriptions }\end{array}$ & $\begin{array}{l}N=122 \text { college } \\
\text { students } / 3 \\
\text { experiments }\end{array}$ & $\begin{array}{l}\text { Experimental } \\
\text { conditions }\end{array}$ & $\begin{array}{l}\text { Anonymity may make } \\
\text { people more likely to } \\
\text { reveal their true desired } \\
\text { self }\end{array}$ \\
\hline $\begin{array}{l}\text { Back et al. } \\
\text { (2010) }\end{array}$ & Personality traits & $\begin{array}{l}\text { Self-reports and friend } \\
\text { reports on actual } \\
\text { personality } \\
\text { Self-reports on ideal self } \\
\text { (personality) } \\
\text { Observer reports of } \\
\text { personality based on SNS } \\
\text { profile information }\end{array}$ & $\begin{array}{l}N=23617-22- \\
\text { year-olds }\end{array}$ & $\begin{array}{l}\text { The most common } \\
\text { SNS in US } \\
\text { and Germany } \\
\text { (Facebook in } \\
\text { US, StudiVZ } \\
\text { and SchuelerVZ } \\
\text { in Germany) }\end{array}$ & $\begin{array}{l}\text { Individuals tend to give } \\
\text { accurate portrayals of } \\
\text { themselves on } \\
\text { Facebook }\end{array}$ \\
\hline $\begin{array}{l}\text { Crowson and } \\
\text { Goulding } \\
(2013)\end{array}$ & Sexual identity formation & $\begin{array}{l}\text { Online interviews (through } \\
\text { instant messaging) }\end{array}$ & $\begin{array}{l}N=12 \text { men } \\
18-33 \text {-year- } \\
\text { olds }\end{array}$ & Virtual worlds & $\begin{array}{l}\text { Experiences online may } \\
\text { aid sexual identity } \\
\text { development } \\
\text { The online identity need } \\
\text { to be transferred to } \\
\text { offline contexts }\end{array}$ \\
\hline Davis (2012) & $\begin{array}{l}\text { Self-presentation } \\
\text { Identity as a construction }\end{array}$ & $\begin{array}{l}\text { Interviews concerning } \\
\text { tensions between } \\
\text { multiple self-expressions } \\
\text { and consistency }\end{array}$ & $\begin{array}{l}N=24 \\
16-25 \text {-year-olds }\end{array}$ & $\begin{array}{l}\text { Variety of online } \\
\text { contexts }\end{array}$ & $\begin{array}{l}\text { Obligations towards self, } \\
\text { others, norms, and } \\
\text { society implicitly limit } \\
\text { self-multiplicity }\end{array}$ \\
\hline Davis (2013) & $\begin{array}{l}\text { Self-concept clarity } \\
\text { Identity expression/ } \\
\text { experimentation }\end{array}$ & $\begin{array}{l}\text { Self-reports of self-concept } \\
\text { clarity and online identity } \\
\text { expression/experimentation }\end{array}$ & $\begin{array}{l}N=207911-19- \\
\text { year-olds }\end{array}$ & Internet in general & $\begin{array}{l}\text { The more online identity } \\
\text { expression/exploration } \\
\text { the less self-concept } \\
\text { clarity, but association } \\
\text { was mediated by } \\
\text { friendship quality }\end{array}$ \\
\hline $\begin{array}{l}\text { DeHaan et al. } \\
\text { (2012) }\end{array}$ & Sexual identity & $\begin{array}{l}\text { Semi-structured } \\
\text { interviews }\end{array}$ & $\begin{array}{l}N=3216-24- \\
\text { year-olds }\end{array}$ & Internet in general & $\begin{array}{l}\text { Online context are used } \\
\text { to explore and make } \\
\text { meaning of one's } \\
\text { sexuality } \\
\text { Offline experiences } \\
\text { interact with internet } \\
\text { use in shaping identities }\end{array}$ \\
\hline $\begin{array}{l}\text { Grasmuck } \\
\text { et al. (2009) }\end{array}$ & Self-presentation & $\begin{array}{l}\text { Content analyses of } \\
\text { Facebook profiles } \\
\text { Interviews }\end{array}$ & $\begin{array}{l}N=63 \text { college } \\
\text { students }\end{array}$ & Facebook & $\begin{array}{l}\text { Strategies for self- } \\
\text { presentations and } \\
\text { expressions of ethnic } \\
\text { identities differed } \\
\text { between racial/ethnic } \\
\text { groups }\end{array}$ \\
\hline $\begin{array}{l}\text { Greenhow } \\
\text { and Robelia } \\
(2009)\end{array}$ & Self-presentation & $\begin{array}{l}\text { Interviews } \\
\text { Think-alouds while engaging } \\
\text { in mySpace page } \\
\text { Content analyses of } \\
\text { MySpace pages }\end{array}$ & $\begin{array}{l}N=1117-19- \\
\text { year-olds }\end{array}$ & MySpace & $\begin{array}{l}\text { Educational, relational, } \\
\text { and physical aspects of } \\
\text { identity were often } \\
\text { revealed, but it was } \\
\text { unusual to reveal } \\
\text { sexual, ethnic and } \\
\text { occupational aspects of } \\
\text { identity }\end{array}$ \\
\hline $\begin{array}{l}\text { Hillier and } \\
\text { Harrison } \\
\text { (2007) }\end{array}$ & Sexual identity & $\begin{array}{l}\text { Questionnaires about } \\
\text { sexuality and internet } \\
\text { experiences } \\
\text { Autobiographical stories }\end{array}$ & $\begin{array}{l}N=95814-21- \\
\text { year-olds }\end{array}$ & Internet in general & $\begin{array}{l}\text { Internet offer a safe-place } \\
\text { to express sexuality and } \\
\text { connect with other } \\
\text { same-sex attracted } \\
\text { young people }\end{array}$ \\
\hline
\end{tabular}


Table 2 continued

\begin{tabular}{|c|c|c|c|c|c|}
\hline Study & Identity definition/focus & Methodology & Participants & Online context & $\begin{array}{l}\text { Main findings and } \\
\text { conclusions }\end{array}$ \\
\hline $\begin{array}{l}\text { Hu et al. } \\
\text { (2015) }\end{array}$ & Identity reconstruction & $\begin{array}{l}\text { Interviews or questionnaires } \\
\text { about revealing } \\
\text { information online and } \\
\text { reasons for hiding or } \\
\text { fabricating information }\end{array}$ & $\begin{array}{l}N=47 \\
\text { community } \\
\text { users }\end{array}$ & QQ (China) & $\begin{array}{l}\text { Anonymous users } \\
\text { reconstruct their } \\
\text { identity online for } \\
\text { several reasons. For } \\
\text { example, to change } \\
\text { their social networks } \\
\text { and due to privacy } \\
\text { concern }\end{array}$ \\
\hline $\begin{array}{l}\text { Jordán-Conde } \\
\text { et al. (2014) }\end{array}$ & $\begin{array}{l}\text { Identity status } \\
\text { Intimate disclosure on } \\
\text { Facebook as a sign of } \\
\text { identity crisis }\end{array}$ & $\begin{array}{l}\text { Identity status questionnaire } \\
\text { Content analyses of } \\
\text { Facebook profiles } \\
\text { (Initial exploratory focus } \\
\text { group) }\end{array}$ & $\begin{array}{l}N=25 \\
\text { College students } \\
(n=918-21- \\
\text { year-olds in } \\
\text { initial focus } \\
\text { group) }\end{array}$ & Facebook & $\begin{array}{l}\text { Intimate disclosure on } \\
\text { Facebook does not } \\
\text { reveal an individual's } \\
\text { identity status } \\
\text { Facebook culture } \\
\text { encourages intimate } \\
\text { disclosure, which is } \\
\text { therefore independent } \\
\text { of identity development }\end{array}$ \\
\hline $\begin{array}{l}\text { Keipi and } \\
\text { Oksanen } \\
(2014)\end{array}$ & $\begin{array}{l}\text { Self-determination } \\
\text { Identity exploration }\end{array}$ & $\begin{array}{l}\text { Coding of narratives about } \\
\text { anonymity online }\end{array}$ & $\begin{array}{l}N=25814-18- \\
\text { year-olds }\end{array}$ & Internet in general & $\begin{array}{l}\text { Adolescents' themselves } \\
\text { view internet } \\
\text { anonymity as involving } \\
\text { opportunities to express } \\
\text { and explore oneself and } \\
\text { build relationships as } \\
\text { well as risks, such as } \\
\text { cyberbullying }\end{array}$ \\
\hline $\begin{array}{l}\text { McKenna and } \\
\text { Bargh } \\
(2000)\end{array}$ & $\begin{array}{l}\text { Social identity } \\
\text { Role identity }\end{array}$ & $\begin{array}{l}\text { Review focused on impact } \\
\text { of internet in general }\end{array}$ & - & Internet in general & $\begin{array}{l}\text { Anonymity may make } \\
\text { people reveal their true } \\
\text { self. }\end{array}$ \\
\hline $\begin{array}{l}\text { Michikyan } \\
\text { et al. (2015) }\end{array}$ & $\begin{array}{l}\text { Self-presentation } \\
\text { Identity coherence }\end{array}$ & $\begin{array}{l}\text { Questionnaire about } \\
\text { identity coherence and } \\
\text { presentations of facets of } \\
\text { the self on Facebook }\end{array}$ & $\begin{array}{l}N=261 \\
\text { emerging } \\
\text { adults, } \\
M_{\text {age }}=22\end{array}$ & Facebook & $\begin{array}{l}\text { A more coherent sense of } \\
\text { identity is related to } \\
\text { presenting the real self } \\
\text { on Facebook, whereas } \\
\text { more uncertainty } \\
\text { concerning identity is } \\
\text { related to presenting a } \\
\text { false self }\end{array}$ \\
\hline $\begin{array}{l}\text { Page et al. } \\
\text { (2013) }\end{array}$ & $\begin{array}{l}\text { Self-presentation } \\
\text { Identity narrative }\end{array}$ & $\begin{array}{l}\text { Status updates on } \\
\text { Facebook } \\
\text { Questionnaires and phone } \\
\text { interviews on Facebook } \\
\text { practices }\end{array}$ & $\begin{array}{l}N=6020-49- \\
\text { year-olds } \\
(n=12 \text { in } \\
\text { interviews })\end{array}$ & Facebook & $\begin{array}{l}\text { Networked narratives are } \\
\text { the new way for people } \\
\text { to tell the story about } \\
\text { who they are }\end{array}$ \\
\hline $\begin{array}{l}\text { Rubin and } \\
\text { McClelland } \\
(2015)\end{array}$ & Sexual identity & $\begin{array}{l}\text { Interviews in person and by } \\
\text { phone about expressing } \\
\text { sexual and racial } \\
\text { identities online }\end{array}$ & $\begin{array}{l}N=8 \text { women } \\
16-19 \text {-year- } \\
\text { olds }\end{array}$ & Facebook & $\begin{array}{l}\text { On Facebook norms } \\
\text { concerning } \\
\text { heterosexuality are } \\
\text { reinforced, which may } \\
\text { make young people } \\
\text { hide their sexual } \\
\text { identities }\end{array}$ \\
\hline $\begin{array}{l}\text { Schmalz et al. } \\
\text { (2015) }\end{array}$ & $\begin{array}{l}\text { Social identity (group } \\
\text { identification) }\end{array}$ & $\begin{array}{l}\text { Questionnaires measuring } \\
\text { the strength of the social } \\
\text { identity (specified as the } \\
\text { fan of a football team) } \\
\text { and SNS-usage while the } \\
\text { social identity was } \\
\text { threatened }\end{array}$ & $\begin{array}{l}N=12019-68- \\
\text { year-olds }\end{array}$ & $\begin{array}{l}\text { Social media sites } \\
\text { such as } \\
\text { Facebook and } \\
\text { Twitter }\end{array}$ & $\begin{array}{l}\text { Stronger sense of in- } \\
\text { group online than } \\
\text { offline } \\
\text { SNS may be used to get } \\
\text { social support and } \\
\text { connect with other with } \\
\text { the same experience } \\
\text { when the social identity } \\
\text { is threatened }\end{array}$ \\
\hline
\end{tabular}


Table 2 continued

\begin{tabular}{|c|c|c|c|c|c|}
\hline Study & Identity definition/focus & Methodology & Participants & Online context & $\begin{array}{l}\text { Main findings and } \\
\text { conclusions }\end{array}$ \\
\hline $\begin{array}{l}\text { Strano and } \\
\text { Wattai } \\
\text { Queen } \\
(2012)\end{array}$ & $\begin{array}{l}\text { Self-presentation } \\
\text { Impression management }\end{array}$ & $\begin{array}{l}\text { Interviews and online } \\
\text { questionnaires about } \\
\text { removing material on } \\
\text { Facebook-suppression } \\
\text { strategies }\end{array}$ & $\begin{array}{l}N=668 \\
18-88 \text {-year-olds } \\
(N=30 \\
18-31+\text { years } \\
\text { old, in } \\
\text { interview } \\
\text { study })\end{array}$ & Facebook & $\begin{array}{l}\text { Most people do remove } \\
\text { tags, but there are } \\
\text { gender and age } \\
\text { differences } \\
\text { Suppression strategies are } \\
\text { important aspects in } \\
\text { dealing with self- } \\
\text { presentations online }\end{array}$ \\
\hline $\begin{array}{l}\text { Valkenburg } \\
\text { et al. (2005) }\end{array}$ & $\begin{array}{l}\text { Self-presentation } \\
\text { Identity experiments }\end{array}$ & $\begin{array}{l}\text { Questionnaires about online } \\
\text { identity experiments (i.e., } \\
\text { pretending to be someone } \\
\text { else online) }\end{array}$ & $\begin{array}{l}N=6009-18- \\
\text { year-olds }\end{array}$ & $\begin{array}{l}\text { Chat or instant } \\
\text { messaging }\end{array}$ & $\begin{array}{l}\text { Young people pretended } \\
\text { to be someone else to } \\
\text { see how others react, to } \\
\text { overcome shyness, and } \\
\text { to facilitate social } \\
\text { interactions } \\
\text { Younger adolescents } \\
\text { were more likely to } \\
\text { pretend to be someone } \\
\text { else }\end{array}$ \\
\hline $\begin{array}{l}\text { Valkenburg } \\
\text { and Peter } \\
(2008)\end{array}$ & $\begin{array}{l}\text { Self-concept clarity } \\
\text { Identity experiments }\end{array}$ & $\begin{array}{l}\text { Questionnaires asking about } \\
\text { self-concept clarity and } \\
\text { identity experiments }\end{array}$ & $\begin{array}{l}N=115810-17- \\
\text { year-olds }\end{array}$ & Internet in general & $\begin{array}{l}\text { Associations between } \\
\text { pretending to be } \\
\text { someone else online } \\
\text { (identity experiments) } \\
\text { and lower self-concept } \\
\text { clarity are explained by } \\
\text { other factors (e.g., } \\
\text { loneliness, social } \\
\text { anxiety) }\end{array}$ \\
\hline $\begin{array}{l}\text { Valkenburg } \\
\text { and Peter } \\
(2011)\end{array}$ & $\begin{array}{l}\text { Self-concept clarity } \\
\text { Self-esteem } \\
\text { Identity processes: self- } \\
\text { presentation and self- } \\
\text { disclosure }\end{array}$ & $\begin{array}{l}\text { Review focused on risks and } \\
\text { opportunities with online } \\
\text { communication }\end{array}$ & - & Internet in general & $\begin{array}{l}\text { Associations between } \\
\text { internet use and self- } \\
\text { concept clarity may not } \\
\text { be asserted }\end{array}$ \\
\hline $\begin{array}{l}\text { Zhao et al. } \\
\text { (2008) }\end{array}$ & Self-presentation & $\begin{array}{l}\text { Coding of Facebook } \\
\text { accounts }\end{array}$ & $\begin{array}{l}N=63 \text { college } \\
\text { students }\end{array}$ & Facebook & $\begin{array}{l}\text { Important to signal } \\
\text { popularity, social } \\
\text { connections and } \\
\text { versatility online } \\
\text { Online identities reflect } \\
\text { the person people want } \\
\text { to be-hoped for } \\
\text { possible selves }\end{array}$ \\
\hline
\end{tabular}

Articles were selected to reflect the different lines of research of identity online (with priority given to newer references) following searches on PsycINFO until August 2015. Combinations of the following search terms were used: identity, online, internet, social media, and social networking sites (SNS)

sexual and ethnic minorities showed that it was common for them to hide their sexual identity on Facebook in order to maintain relations within the family (Rubin and McClelland 2015). To hide their sexual identity in contexts online in order to avoid a stigma may limit the possibility to find support in groups with other people with similar experiences, the exact same thing that previous research showed to be so crucial for identity development. With regards to future research the main conclusion that may be drawn from the discrepancies between these studies is that it is essential to take both processes of hiding and of revealing aspects of identity into account when trying to understand the meaning of online contexts for adolescents' identity development.

With regards to the relation between online activities and more general aspects of identity development the reviewed research also showed that the associations may not be as straightforward and easy to predict as some of the hypotheses tested so far have suggested. For example, in one of the few studies that aimed to link internet usage to aspects of identity development beyond what goes on in online contexts it was found that young people who 
disclosed more intimate material on Facebook were not more likely to be involved in a process of active identity exploration (Jordán-Conde et al. 2014), as the hypothesis tested indicated. Somewhat contrary, Michikyan, Dennis, and Subrahmanyam (2015) showed that adolescents with a more coherent sense of identity also reported to show their real self on Facebook, whereas individuals with a more incoherent sense of identity where more likely to report incongruent self-expressions on Facebook. These findings indicate that individuals who experience uncertainty with regard to their identity are more likely to use online contexts for identity experiments and that those with a more coherent sense of identity have more integration between different contexts.

Research also shows individual differences in the meaning of online contexts. For example, one study (Davis 2013) showed that, the comparably few, individuals who mainly used the internet to express and explore aspects of their identity reported lower self-concept clarity, whereas individuals who mainly used the internet to interact with their offline friends reported higher self-concept clarity. These findings indicate that the meaning of online contexts in adolescents' identity development may vary between individuals depending on the ways they use online contexts and their reasons for doing so.

To summarize, the research reviewed here shows that online contexts may be particularly salient for explorations of aspects of identity that may not be expressed in individuals' offline contexts. Less is known about how this impacts the sense of identity across contexts and beyond specific social identities, particularly since the few available studies revealed somewhat inconsistent findings.

\section{Means for Self-Presentations: Anonymity and Disembodiment in Online Contexts have Implications for Identity Development}

Some of the characteristics of online contexts that distinguish them the most from other contexts of identity development are the ways in which anonymity and disembodiment may make self-presentations in these contexts more or less independent of offline identities and physical appearances (McKenna and Bargh 2000; Turkle 1995). Paradoxically, visibility and possible audiences are also more extensive online than anywhere else. These characteristics of online contexts thus bring possibilities to both hide and be seen online.

The opportunities to experiment with self-presentations may be greater than in offline contexts, but these aspects of online contexts also include risks. For example, experiences of deindividuation-reduced self-awareness and responsibility for one's action (McKenna and Bargh 2000), may lead to antisocial behaviours in online contexts. Other potential problems may be difficulties in integrating multiple self-presentations (Davis 2012). What has been labelled the "fragmentation hypothesis" (Valkenburg and Peter 2011) describes the hypothesis that the multiple selfpresentations that contemporary adolescents have to handle may lead to a sense of identity that is diffused and shattered. However, the contrary hypothesis, labelled the "unity hypothesis" (Valkenburg and Peter 2011), states that the many self-presentations lead to a strengthened sense of identity and identity integration as it forces individuals to make conscious choices based on their views of who they are. Thus, aspects of online contexts may be assumed to both facilitate and hinder identity development.

As seen in Table 2, most recent research on identity online solely investigates usage of SNS, and most often one specific SNS; Facebook. At least on Facebook research shows that people's profiles reflect their actual personality (Back et al. 2010), but a common factor also appear to be the presentation of a socially desirable and acceptable self (e.g., Page et al. 2013; Zhao et al. 2008). These findings indicate that the extreme and sometimes unforeseeable visibility online make people more cautious about what they reveal about themselves online. It has also been found that people adjust their online self-presentations depending on the imagined audience and that impression management (Goffman 1959) online is performed through choosing what to display (Page et al. 2013; Zhao et al. 2008), but also through removing material concerning oneself that others display (Strano and Wattai Queen 2012). Together, these studies of SNS usage show how some online contexts may lead to a heightened self-consciousness and advanced strategies for impression management.

From a developmental perspective, a particularly interesting finding in the reviewed literature is that late adolescents expressed little worry over what they displayed online (Jordán-Conde et al. 2014), but also that younger people are more likely to engage in impression management online than are older people (Strano and Wattai Queen 2012). These findings indicate that there certainly are developmental aspects involved in individuals' usage of online contexts and that for example, cognitive development might be related to how individuals' understand the consequences of their behaviours online. These findings thus indicate that the meaning of online contexts for identity development might be different at different ages.

There is a dearth of research that considers the diversity of online contexts when investigating identity development. In online contexts where common interests are the main motivation behind interactions (e.g., special-interestblogs, discussions on twitter etc.), and not primarily friendships like on Facebook and other similar SNS (boyd 2014; Reich et al. 2012), individuals may interact in other ways and express sides of themselves that they do not, or 
cannot, show in their everyday offline contexts, or on SNS such as Facebook. In one study that did focus on anonymous contexts (Hu et al. 2015), it was concluded that individuals could reconstruct their online identities in anonymous contexts both in order to escape old social networks and to access new ones. Thus, anonymous contexts may offer other opportunities for identity development than the more common everyday contexts, such as Facebook.

Even though they differ in how often they do so, most young people are aware of the possibility to seek out anonymous contexts (e.g., web forums or online games, boyd 2014) and do partake in them as well. In one study it was found that adolescents' themselves viewed internet anonymity as involving opportunities to express and explore oneself as well as risks, such as cyberbullying (Keipi and Oksanen 2014). Anonymous contexts may contribute to identity development in ways that go beyond the more mainstream usage of SNS, as they allow individuals to explore those aspects of identity that are not revealed in their everyday online and offline contexts. It may well be that it is precisely these contexts that are the most important in identity development.

In our view, the focus in research on SNS where individuals' interact with their offline persona has lead research to oversee the aspects of anonymity and disembodiment that are present also in those contexts. Even though the online contexts where many young people spend much of their time (i.e., SNS) are places where they show their offline persona, the possibility to experiment with, or to conceal your identity is greater online than in any other contexts. An example are the accepted "white lies" that adolescents use on SNS such as Facebook, for example, to state another age than their own in order to meet the age limits or to use the relationships status to communicate different social affiliations (Jordán-Conde et al. 2014). These accepted ways of experimenting with self-presentations also in contexts where they are not anonymous mean that young people early on learn that there are ways of hiding or experimenting with aspects of their identity online.

Aspects of anonymity and disembodiment may also contribute to the somewhat restrictive self-presentations online as these aspects make the response from others more indirect and difficult to interpret. Disembodied online interactions make it more difficult to interpret people's reactions, and to foresee the audiences of online activities (Suler 2005), which may in turn heighten self-consciousness and insecurity. Hence, anonymity and disembodiment are likely to affect interactions in most online contexts, but the focus on SNS where individuals are not anonymous per see, has led research to oversee the influence of these aspects of online contexts on adolescents' identity development.

\section{Requisites for Social Interactions: Online Contexts offer Unprecedented Opportunities for Autonomy and a Private Space}

In adolescence when identity development is a primary developmental challenge, young people strive to find contexts where they can experiment with new abilities, values, and ideals, and this may require both psychological and physical distance from parents and other adult authority figures (Erikson 1968). Adolescents thus need to find a place of their own, relatively free from adult supervision. Today, online contexts offer such a place (boyd 2014) and this private space online distinguishes itself from offline contexts with regards to the ways in which social interactions take place. These changes, in turn, have consequences for identity development. To find a place of one's own is a key aspect of identity development in adolescence, and adolescents' use of online contexts shows how strong this need is and how salient it is for identity development. To understand adolescents' identity development today it is thus important to understand what goes on between adolescents online and the developmental implications of this identity work.

One important aspect of the social interactions online is that the place of their own that adolescents' create online may have lower levels of adult supervision than any other context where adolescents interact. As today's youth are often described as the first digital natives (Prensky 2001) and their parents as digital immigrants, their parents may have difficulties in finding a balanced involvement in their adolescents' online lives. Therefore, parents risk being both too involved and hinder autonomy and identity development, and too little involved when their support actually is needed. This is one example of how online contexts create new conditions for adolescents' identity development with regards to establishing a sense of autonomy (Manago 2015) and exploring their identity (Shapiro and Margolin 2014). A furthered understanding of adolescents identity development online can thus make it easier to help parents (as well as teachers and others who interact with adolescents) support adolescents' development without risking be either under- or overinvolved.

When adolescents are searching for their identity, the contexts they create or find online may be associated with group identifications that may offer relief from the distress and confusion associated with identity development. In an investigation of a specific social identity (being a fan of a football team) and internet usage, Schmalz, Colistra, and Evans (2015) argued that, overall, in-group experiences may be even stronger online than offline. In spite of the sense of belonging that these group identifications may offer, they may also have negative consequences for ado- 
lescents' development. These negative consequences may be those associated with more destructive behaviors directed either toward the self or toward others (for example pro ana forums devoted to promoting Anorexia Nervosa, or internet hate sites). On the positive side, online contexts offer unparalleled opportunities for adolescents to find a group where they belong and that recognizes them for who they are. Thus, online contexts offer opportunities for group identifications that involve both opportunities and risks with regards to identity development.

Related to the issue of group identifications and given the importance of social interactions in adolescents' identity development, another interesting finding from the reviewed research, is that it also showed how self-presentations online are constructed together with other people. Page et al. (2013, p. 192), therefore, proposed the construct "Networked Narratives" to describe how people construct their life-stories together with other people online. This construct highlights that identity development (online) is not just the individual creating a story about themselves (an identity narrative), but many different people contribute to the individual's online identity narrative. For example, to not adhere to norms and expectations from others (also generalized others) concerning what to display in online contexts may lead to social sanctions (Davis 2014). Thus, identity development online are strongly influenced by other people and individuals create their online identity narrative together with other people.

The reviewed research offer important insights into aspects of identity development that goes on online, however, the ways in which online networked narratives are integrated into individuals' overall life-stories (or identity narratives, see e.g., McAdams 2001) remains to be addressed in research. Another issue that remain to be answered is how social interactions in different online contexts impact adolescents' identity development through, for example, the processes described by the construct networked narratives, as well as through other processes. Thus, an important issue for future research to address is how young people's interactions online contribute to their identity narrative.

\section{Discussion}

In this study, we reviewed the research on identity online from a developmental perspective in order to investigate what the identity definitions, methodologies, participants, online contexts, and main findings and conclusions from this research tell us about the meaning of online contexts in adolescents' identity development.

Online contexts offer conditions that make them different from other contexts where adolescents interact and develop. In short the reviewed articles revealed that identity explorations may be facilitated by access to contexts online (Crowson and Goulding 2013; DeHaan et al. 2012), but also that characteristics of some online contexts, particularly SNS such as Facebook, may make individuals more cautious about what they reveal about themselves (Page et al. 2013; Strano and Wattai Queen 2012) and even make them hide salient aspects of their identity (Rubin and McClelland 2015). The reviewed research also implied age differences in how much individuals worry over what they display online (Jordán-Conde et al. 2014) and in strategies for impression management (Strano and Wattai Queen 2012). These findings indicate that the meaning of online contexts may vary by developmental periods. Finally, the reviewed literature showed the strong influence of other people on adolescents' identity development online (Davis 2014) and how online identity narratives are constructed together with other people (Page et al. 2013). Thus, as we have argued throughout this article, online contexts bring about changed conditions with regard to the opportunities for identity explorations, the means for self-presentations, and the requisites for social interaction.

In our review, we also identified several limitations in the literature on identity online with regard to this research's ability to answer developmentally informed research questions. Specifically, this review showed that research on identity online has primarily dealt with identity expressions, but less with identity development. The main focus has been on self-presentations (Page et al. 2013); specific aspects of identity (such as sexuality, Crowson and Goulding 2013); and to a lesser extent the relations between internet usage and psychosocial development (e.g., Davis 2013). The reviewed research of identity online represented a variety of disciplines and this may explain why the concept of identity was used in multiple ways and with definitions that differed substantially between studies (see Table 2). While most research defined identity as selfpresentations or social identities, some studies focused on aspects of identity development such as exploration and experimentation (e.g., Valkenburg and Peter 2008), but often through the study of explicit forms of self-presentations and less through developmental processes. Still others defined identity as a sense of coherence and sameness (e.g., Davis 2013; Valkenburg and Peter 2011). This latter definition may be closest to the way a sense of identity is conceptualized in developmental research (see e.g., McLean and Syed 2015), but a developmental perspective also offers a framework for the study of the processes through which this sense of identity develops. From a developmental perspective, what the reviewed research on identity online is lacking is a clear conceptual framework for addressing research questions concerning the role of online contexts in adolescents' identity development. 


\section{Future Directions}

Based on this review, we propose three broad directions for future research programs aiming to understand the meaning of online contexts to adolescents' identity development. First, research could benefit from a focus on identity integration: how are online and offline aspects of identity integrated and how do they contribute to the overall sense of identity? Second, related to the issue of identity integration, we also suggest that research examines the ways in which different identity processes play out in different contexts. Are similar processes of identity development involved in online and offline contexts, or could additional processes be involved in identity development online? Finally, in order to fully understand the meaning of online contexts in identity development, research needs to focus more on diversity with regards to contexts and individuals: How does the meaning of online contexts in identity development vary between different online and offline contexts? How do these meanings differ between individuals, with regards to for example gender and socio-economic status, and across development? Below we specify our suggestions for future research for each of the three themes from the review.

\section{Opportunities for Identity Explorations}

The reviewed research that concerned identity explorations did not address how online identity explorations impact the sense of identity across contexts and beyond specific social identities. This issue could be addressed by measures of the extent to which self-presentations across different contexts differ or resembles each other (i.e., spatial integration, van Hoof and Raaijmakers 2002), how online and offline aspects of identity are configured (Schachter 2004), and how individuals make meaning of differences and similarities between their views of themselves across contexts (McAdams 2001). Longitudinal studies could investigate the processes (e.g., exploration, commitment, Kroger and Marcia 2011; Meeus 2011, meaning-making, McAdams 2001, or others) that may lead to identity integration (Syed and McLean 2016). For example, do individuals first explore certain aspect of their identity in an online context, then make commitments in that context, continue to explore the meaning of that aspect to their overall sense of identity, and then commit in order to express that aspect of themselves in other contexts as well? Or, are other processes involved in identity development online?

Future research also need to investigate whether the findings from research on sexual identity-that integration across contexts is needed (Crowson and Goulding 2013), applies to other aspects of identity development as well. Which are the circumstances when it becomes problematic if identity development online and offline, or in different online contexts, are separate and not integrated? It may be that this separation varies in how troublesome it is depending on developmental stage, which aspect of identity it involves, and the importance that a particular aspect of identity has to the individuals overall sense of identity. Indeed, feeling like a completely different person in contexts online compared to other contexts could lead to experiences of identity diffusion (Erikson 1968; Turkle 1995) - a sense of not knowing who one is, and as a consequence psychological distress. However, the validation of aspects of identity that is difficult to express offline that may be found online could also be associated with positive outcomes. It is thus also important to investigate how and when identity integration between online and offline contexts are related to mental health and well-being.

\section{Means for Self-Presentations}

With regards to the understanding of the changed means for self-presentations that online contexts bring about, an area for future studies is how cognitive development is associated with sensitivity to feedback on online self-presentations and the ways in which adolescents foresee the audiences of their online behavior. Younger adolescents may have more difficulties in taking the perspective of the multiple audiences online (friends, family, strangers, etc.) and may be more affected by the anonymity and disembodiment that characterize online interactions. Reactions from different more or less foreseeable audiences may impact their identity development to a larger extent than it does for older adolescents or adults. They might, for example, be more easily swayed in their identity explorations and more likely to question their commitments. Thus, one area of inquiry for future research is to link abilities for perspective-taking (and other cognitive abilities), others' reactions (both real and imagined) to selfpresentations online, and identity development (in terms of for example exploration and commitment) to understand more about how internet usage interact with identity development.

\section{Requisites for Social Interactions}

Given that online contexts are likely to offer opportunities for adolescents' to create a place of their own-a place that might involve less adult supervision than any other context where adolescents meet and interact-what appear to be missing in the research reviewed in this article is research programs aiming to learn more about identity development in general by studying what goes on in online contexts. Research in offline contexts shows that different contexts may have different meaning and varying influence on 
identity development (Frisén and Wängqvist 2011; McLean, Syed, Yoder, and Greenhoot 2014) and that identity aspects from different contexts may be configured in various ways (Schachter 2004). The same may hold for online contexts. A future research area is thus how adolescents' development with regards to autonomy and the creation of a private space in online contexts is related to other aspects of their identity development.

Several existing methods used to study identity development could be adjusted to also suit investigations that include online contexts. For example, questionnaires (Crocetti et al. 2008; Luyckx et al. 2008) or identity interviews (Kroger and Marcia 2011) designed to measure identity exploration and commitment in various domains could be adapted to include investigations of these processes in online contexts. Narrative prompts could be designed to include events that have happened online and then analysed for processes such as meaning-making (McAdams 2001) and the ways in which individuals make sense of and integrate their roles across online and offline contexts. Such research could yield knowledge of the ways in which online contexts are similar to or differ from other contexts in terms of their meaning for adolescents' identity development and the unique contribution to identity development that may come from involvement in online contexts.

A final issue concerns that online contexts certainly offer a private space for adolescents' to explore and develop their identities, but it would be wrong to treat these contexts as one singular context. Future research aiming to understand the meaning of online contexts in identity development need to further explore the diversity of online contexts with regards to for example anonymity, potential audiences, and online/offline overlap. The "place of their own" that youth establish online represent a diverse variety of contexts and the affordances of these contexts are likely to vary between individuals; in relation to for example gender, socio-economic status, age, and developmental stage; as well as in relation to the ways they use these contexts and their reasons for doing so.

\section{Limitations}

A limitation with the present study is that we limited our review to research that explicitly addressed identity issues in their investigations of online contexts. A broader focus on related lines of research might also have contributed to the understanding of the meaning of online contexts in identity development. However, the contribution from this review is that it offers an understanding of the ways identity has been addressed in research on online contexts and internet usage. This understanding in turn, helped identify what may be learned about contemporary adolescents' identity development from this research, as well as how a developmental framework may inform future research programs.

For this review, we decided to primarily include newer articles (from 2010 and forward). Another approach, with equal priority given to newer and older references, might have yielded additional knowledge concerning how the conditions for identity development in online contexts have changed since people started using the internet until the present. However, since online contexts are constantly changing our approach made sure that this review included the most relevant research in order to understand the meaning of online contexts in contemporary adolescents' development.

\section{Conclusions}

In this review of research concerning identity online, three areas through which online contexts may impact identity development were addressed from the perspective of adolescents' identity development: identity explorations, selfpresentations, and social interactions. These areas revealed that aspects of identity that are constrained in offline contexts may be expressed and explored online, that anonymity and disembodiment in online contexts have implications for adolescents' identity development, and that online contexts offer unprecedented opportunities for adolescents' autonomy development and their creation of a private space. In short, online contexts offer opportunities for adolescents to explore aspects of themselves that they may not reveal on other contexts. Online contexts, particularly SNS, may also lead adolescents to present themselves in a more restrictive way, but the sensitivity and adjustment to how others perceive them may be related to other aspects of development. Finally, online adolescents may establish a place of their own, more freed from adult supervision than other context, and this may be associated with both opportunities and risks in terms of identity development. To conclude, we argue that developmental theories of identity have the potential of furthering the understanding of the meaning of online contexts in identity development and, equally important, research on identity development should take online contexts into account in order to grasp the whole story of adolescents' identity development in contemporary society.

Acknowledgments Grants from the Swedish Research Council for Health, Working Life and Welfare (FORTE) and Stiftelsen Clas Groschinskys Minnesfond enabled this research. 
Authors' Contributions MW conceived of the study, participated in its design and coordination and drafted the manuscript; AF conceived of the study, participated in its design and coordination and helped to draft the manuscript. All authors read and approved the final version of this manuscript.

\section{Compliance with Ethical Standards}

Conflicts of interest The authors report no conflict of interests.

Funding Grants from the Swedish Research Council for Health, Working Life and Welfare (FORTE) and Stiftelsen Clas Groschinskys Minnesfond enabled this research.

Ethical Approval Since this article does not concern original research, but a review of research no ethics approval has been issued or applied for.

Informed Consent Since this article does not concern original research, there are no participants from which to collect informed consent.

\section{References}

Back, M. D., Stopfer, J. M., Vazire, S., Gaddis, S., Schmukle, S. C., Egloff, B., \& Gosling, S. D. (2010). Facebook profiles reflect actual personality, not self-idealization. Psychological Science, 21, 372-374. doi:10.1177/0956797609360756.

Bargh, J. A., McKenna, K. Y. A., \& Fitzsimons, G. M. (2002). Can you see the real me? Activation and expression of the "True self" on the internet. Journal of Social Issues, 58, 33-48. doi:10. $1111 / 1540-4560.00247$.

boyd, d. (2014). It's complicated: The social lives of networked teens. New Haven: Yale University Press.

Carlsson, J., Wängqvist, M., \& Frisén, A. (2015). Identity development in the late twenties: A never ending story. Developmental Psychology, 51, 334-345. doi:10.1037/a0038745.

Crocetti, E., Rubini, M., \& Meeus, W. (2008). Capturing the dynamics of identity formation in various ethnic groups: Development and validation of a three-dimensional model. Journal of Adolescence, 31, 207-222. doi:10.1016/j.adolescence. 2007.09.002.

Crowson, M., \& Goulding, A. (2013). Virtually homosexual: Technoromanticism, demarginalisation and identity formation among homosexual males. Computers in Human Behavior, 29, A31-A39. doi:10.1016/j.chb.2013.01.017.

Davis, K. (2012). Tensions of identity in a networked era: Young people's perspectives on the risks and rewards of online selfexpression. New Media \& Society, 14, 634-651. doi:10.1177/ 1461444811422430

Davis, K. (2013). Young people's digital lives: The impact of interpersonal relationships and digital media use on adolescents' sense of identity. Computers in Human Behavior, 29, 2281-2293. doi:10.1016/j.chb.2013.05.022.

Davis, J. L. (2014). Triangulating the self: Identity processes in a connected era. Symbolic Interaction, 37, 500-523. doi:10.1002/ symb.123.

DeHaan, S., Kuper, L. E., Magee, J. C., Bigelow, L., \& Mustanski, B. S. (2012). The interplay between online and offline explorations of identity, relationships, and sex: A mixed-methods study with LGBT youth. Journal of Sex Research, 50, 421-434. doi:10. 1080/00224499.2012.661489.

Erikson, E. H. (1968). Identity youth and crisis. New York: Norton. Erikson, E. H. (1980). Identity and the life cycle. New york: Norton.
Frisén, A., \& Wängqvist, M. (2011). Emerging adults in Sweden: Identity formation in the light of love, work and family. Journal of Adolescent Research, 26, 200-221. doi:10.1177/ 0743558410376829.

Goffman, E. (1959). The presentation of self in everyday life. London: Penguin Books.

Grasmuck, S., Martin, J., \& Zhao, S. (2009). Ethno-racial identity displays on facebook. Journal of Computer-Mediated Communication, 15, 158-188. doi:10.1111/j.1083-6101.2009.01498.x.

Greenhow, C., \& Robelia, B. (2009). Informal learning and identity formation in online social networks. Learning, media and Technology, 34, 119-140. doi:10.1080/17439880902923580.

Hillier, L., \& Harrison, L. (2007). Building realities less limited than their own: Young people practising same-sex attraction on the internet. Sexualities, $10, \quad 82-100 . \quad$ doi:10.1177/ 1363460707072956.

Hu, C., Zhao, L., \& Huang, J. (2015). Achieving self-congruency? Examining why individuals reconstruct their virtual identity in communities of interest established within social network platforms. Computers in Human Behavior, 50, 465-475. doi:10.1016/j.chb.2015.04.027.

Jordán-Conde, Z., Mennecke, B., \& Townsend, A. (2014). Late adolescents identity definition and intimate disclosure on Facebook. Computers in Human Behavior, 33, 356-366. doi:10.1016/ j.chb.2013.07.015.

Keipi, T., \& Oksanen, A. (2014). Self-exploration, anonymity and risks in the online setting: Analysis of narratives by 14-18-year olds. Journal of Youth Studies, 17, 1097-1113. doi:10.1080/ 13676261.2014 .881988$.

Kroger, J., \& Marcia, J. E. (2011). The identity statuses: Origins, meaning and interpretations. In S. J. Schwartz, K. Luyckx, \& V. L. Vignoles (Eds.), Handbook of identity: Theory and research (pp. 31-53). New York: Springer.

Kroger, J., Martinussen, M., \& Marcia, J. E. (2010). Identity status change during adolescence and young adulthood: A metaanalysis. Journal of Adolescence, 33, 683-698. doi:10.1016/j. adolescence.2009.11.002.

Luyckx, K., Schwartz, S. J., Berzonsky, M. D., Soenens, B., Vansteenkiste, M., Smits, I., \& Goossens, L. (2008). Capturing ruminative exploration: Extending the four dimensional model of identity formation in late adolescence. Journal of Research in Personality, 42, 58-82. doi:10.1016/j.jrp.2007.04.004.

Manago, A. (2015). Identity development in a digital age: The case of social networking sites. In K. C. McLean \& M. Syed (Eds.), The Oxford handbook of identity development (pp. 508-524). New York: Oxford Press.

Markstrom, C. A. (2011). Identity formation of American Indian adolescents: Local, national, and global considerations. Journal of Research on Adolescence, 21, 519-535. doi:10.1111/j.15327795.2010.00690.x.

McAdams, D. P. (2001). The psychology of life stories. Review of General Psychology, 5, 100-122. doi:10.1037/1089-2680.5.2.100.

McKenna, K. Y. A., \& Bargh, J. A. (2000). Plan 9 from cyberspace: The implications of the internet for personality and social psychology. Personality and Social Psychology Review, 4, 57-75. doi:10.1207/S15327957PSPR0401_6.

McLean, K. C., \& Syed, M. (2015). Oxford handbook of identity development. Oxford, UK: Oxford University Press.

McLean, K. C., Syed, M., Yoder, A., \& Greenhoot, A. F. (2014). The role of domain content in understanding identity development processes. Journal of Research on Adolescence,. doi:10.1111/ jora. 12169.

Meeus, W. (2011). The study of adolescent identity formation 2000-2010: A review of longitudinal research. Journal of Research on Adolescence, 21, 75-94. doi:10.1111/j.1532-7795. 2010.00716.x. 
Michikyan, M., Dennis, J., \& Subrahmanyam, K. (2015). Can you guess who I am? Real, ideal, and false self-presentation on Facebook among emerging adults. Emerging Adulthood, 3, 55-64. doi:10.1177/2167696814532442.

Page, R., Harper, R., \& Frobenius, M. (2013). From small stories to networked narrative: The evolution of personal narratives in Facebook status updates. Narrative Inquiry, 23, 192-213. doi:10. 1075/ni.23.1.10pag.

Prensky, M. (2001). Digital natives, digital immigrants part 1. On the Horizon, 9, 1-6. doi:10.1108/10748120110424816.

Reich, S. M., Subrahmanyam, K., \& Espinoza, G. (2012). Friending, IMing, and hanging out face-to-face: Overlap in adolescents' online and offline social networks. Developmental Psychology, 48, 356-368. doi:10.1037/a0026980.

Rubin, J. D., \& McClelland, S. I. (2015). 'Even though it's a small checkbox, it's a big deal': stresses and strains of managing sexual identity(s) on Facebook. Culture, Health \& Sexuality, 17, 512-526. doi:10.1080/13691058.2014.994229.

Schachter, E. P. (2004). Identity configurations: A new perspective on identity formation in contemporary society. Journal of Personality, 72, 167-200. doi:10.1111/j.0022-3506.2004.00260.x.

Schmalz, D. L., Colistra, C. M., \& Evans, K. E. (2015). Social media sites as a means of coping with a threatened social identity. Leisure Sciences, 37(1), 20-38. doi:10.1080/01490400.2014. 935835.

Schwartz, S. J., Luyckx, K., \& Vignoles, V. L. (Eds.). (2011). Handbook of identity theory and research. New York: Springer.

Shapiro, L. A. S., \& Margolin, G. (2014). Growing up wired: Social networking sites and adolescent psychosocial development. Clinical Child and Family Psychology Review, 17, 1-18. doi:10.1007/s10567-013-0135-1.
Strano, M. M., \& Wattai Queen, J. (2012). Covering your face on Facebook: Suppression as identity management. Journal of Media Psychology: Theories, Methods, and Applications, 24, 166-180. doi:10.1027/1864-1105/a000076.

Suler, J. (2005). The online disinhibition effect. International Journal of Applied Psychoanalytic Studies, 2, 184-188. doi:10.1002/aps.42.

Syed, M., \& McLean, K. C. (2016). Understanding identity integration: Theoretical, methodological, and applied issues. Journal of Adolescence, 47, 109-118. doi:10.1016/j.adolescence.2015.09. 005.

Turkle, S. (1995). Life on the screen: Identity in the age of the internet. New York: Simon \& Schuster.

Valkenburg, P. M., \& Peter, J. (2008). Adolescents' identity experiments on the internet. Consequences for social competence and self-concept unity. Communication Research, 35, 208-231. doi:10.1177/0093650207313164.

Valkenburg, P. M., \& Peter, J. (2011). Online communication among adolescents: An integrated model of its attraction, opportunities, and risks. Journal of Adolescent Health, 48, 121-127. doi:10. 1016/j.jadohealth.2010.08.020.

Valkenburg, P. M., Schouten, A. P., \& Peter, J. (2005). Adolescents' identity experiments on the internet. New Media \& Society, 7, 383-402. doi:10.1177/1461444805052282.

van Hoof, A., \& Raaijmakers, Q. A. W. (2002). The spatial integration of adolescent identity: its relation to age, education, and subjective well-being. Scandinavian Journal of Psychology, 43, 201-212. doi:10.1111/1467-9450.00288.

Zhao, S., Grasmuck, S., \& Martin, J. (2008). Identity construction on facebook: Digital empowerment in achored relationships. Computers in Human Behavior, 5, 1816-1836. doi:10.1016/j.chb. 2008.02.012. 